\title{
Backpropagation Neural Network Modeling for Fault Location in Transmission Line $150 \mathrm{kV}$
}

\author{
${ }^{1,2}$ Azriyenni, ${ }^{1}$ MW Mustafa, ${ }^{2}$ DY Sukma, ${ }^{2}$ ME Dame \\ ${ }^{1}$ Electrical Engineering, Fakulti Kejuruteraan Elektrik, Universiti Teknologi Malaysia \\ Power System Simulation Lab 19a, Skudai, 81300, Johor, Malaysia \\ ${ }^{2}$ Teknik Elektro, Fakultas Teknik, Universits Riau \\ Kampus Bina Widya, Jl. Soebrantas KM 12.5 Pekanbaru, 28293, Indonesia \\ Email: azriyenni@unri.ac.id
}

\begin{abstract}
Abstrak
Dalam penelitian ini disampaikan tentang backpropagation neural network untuk mendeteksi lokasi gangguan di saluran transmisi $150 \mathrm{kV}$ antara gardu induk ke gardu induk. Relay jarak adalah salah satu peralatan perlindungan yang baik dan peralatan keselamatan yang sering digunakan pada saluran transmisi $150 \mathrm{kV}$. Gangguan dalam sistem tenaga yang digunakan adalah peralatan relay jarak dalam saluran transmisi. Namun, perlu lebih meningkatkan beban besar dan sistem jaringan meningkat kompleks. Sistem proteksi menggunakan kontrol digital, untuk menghindari kesalahan perhitungan dari setting impedansi rele jarak dan menghabiskan waktu akan lebih efisien. Kemudian backpropagation neural network adalah model komputasi yang menggunakan proses pelatihan dapat digunakan untuk memecahkan masalah keterbatasan kerja perlindungan relay jarak. Jaringan saraf backpropagation tidak memiliki keterbatasan pengaturan rentang impedansi. Jika output memberikan hasil yang salah, maka bobot dapat diminimalkan dan juga respon dari galat, jaringan saraf backpropagation diharapkan lebih dekat dengan nilai yang benar. Pada akhirnya, pemodelan backpropagation neural network dapat mendeteksi letak kesalahan dan mengidentifikasi arus keluaran circuit breaker trip. Hasil pengujian ini dilakukan pada sistem 150 kV Riau Region.
\end{abstract}

Kata kunci: jaringan syaraf tiruan perambatan balik, relai jarak, impedansi, jalur transmisi, zona

\begin{abstract}
In this topic research was provided about the backpropagation neural network to detect fault location in transmission line $150 \mathrm{kV}$ between substation to substation. The distance relay is one of the good protective device and safety devices that often used on transmission line $150 \mathrm{kV}$. The disturbances in power system are used distance relay protection equipment in the transmission line. However, it needs more increasing large load and network systems are increasing complex. The protection system use the digital control, in order to avoid the error calculation of the distance relay impedance settings and spent time will be more efficient. Then backpropagation neural network is a computational model that uses the training process that can be used to solve the problem of work limitations of distance protection relays. The backpropagation neural network does not have limitations cause of the impedance range setting. If the output gives the wrong result, so the correct of the weights can be minimized and also the response of galat, the backpropagation neural network is expected to be closer to the correct value. In the end, backpropagation neural network modeling is expected to detect the fault location and identify operational output current circuit breaker was tripped it. The tests are performance with interconnected system $150 \mathrm{kV}$ of Riau Region.
\end{abstract}

Keywords: backpropagation neural network, distance relay, impedance, transmission line, zone

\section{Introduction}

Protective systems include circuit breakers and relays are required to run function during normal operation power system. Distance Relay is used as a safety on transmission line due to have ability to avoid fault clearing are very quickly and tuning the relative easy. Fault location is very important for the power system restoration after the fault clearance. Most of power systems blackouts occur are following the loss of successive that was unscheduled power system element outages in a very short period of time during which a system operator cannot respond quickly to prevent the occurrence of the blackout. The applications of artificial intelligent for fault location have been proposed. The application of fuzzy relations for fault 
location was proposed $[2,5]$. They investigated the construction of fuzzy relations for alarm processing and fault location in electrical power systems. The among Fuzzy associations system components that are: relays and circuit breakers have been established with the aid of human experts through their experience and knowledge on protection devices operation for faults involving different system component. In other research, distance relaying scheme is based on fuzzy neural network [3,7]. The classifier uses normalize peaks of voltage and current waveforms as input whereas fault location. The among fuzzy relations alarm patterns and possibly faulted system components are established and employed as training sets for artificial neural networks. That methodology has tested using the seven bus systems real Brazilian system. The artificial neural network have been successfully apply to many power systems $[4,6$, 8]. With the information provided by scada used to detection fault sections. The neural classifiers are trained off line using several different training alarm patterns. They are employed for producing real time classifications; this is in order to obtain final diagnoses from the classification results.

Coordination of distance relays for transmission line parameters are based on the estimate amount of disturbance compensation is calculated off line quickly and tuning the relative easy. But with the situation of the system are always changed that has resulted in the transmission line parameters. It is also changing, it cannot be predicted magnitude fault, the otherwise the existing relay settings cannot be effectived on usage it. The main protection system may be fail, protections should act as backup either in the same station or in neighbor lines with time delay according to the selectivity requirements. The all of determination time delay backup relays which is known as coordination of the protection system. For the provision was selective properties in relay protection of the properties to distinguish or determine which parts of the system impaired can be done with two ways; (a) Pilot System Relaying, the word pilot mean is the end of the transmission put line the information which it can deliver mutual information. The working principle of this pilot relay is provision of information via the conductors from a telephone circuit as physical media. The high frequency signals are coupled to the power transmission line itself from one relay to the other relays, this device known as PLC. (b) Working time delay system relay, there is giving slowness working time for each relays, it can get coordination of work in order to obtain a more both among the relay.

In electrical power system hurt unexpected failures in transmission lines due to various random causes. For all that, service must be urgently restored as transmission line in which a fault occurred cannot be keeped as indefinitely isolated. The fault location algorithms may be developed according to followe the basic procedure, that is: implementation on distance relays used to protect transmission lines in order to make assure the reliability of system at all time. And then, the system implementation on fault location either local or centralized. It can be used to determine accurately the point at whichis fault occurredd to be able to perform required repair or maintenance operations. Power system protection is designed to isolate power system faulted components whenever a disturbance occurs. Quickness, selectivity and coordination are among the most desirable features of a protection system. In the case of disturbances, faulted components must be isolated very quickly in order to reduce the risk of damage in system electrical devices. Besides that, the interruption of energy supply must be minimize or avoided [2]. The protection devices should operate in a coordinated scheme, to guarantee that only the faulted components are disconnected. These devices must also provide backup protection if the protection device responsible for isolating the faulted component does not operate properly, other protection devices must operate in order to eliminate the fault. When this happens a large area in power system will be disconnected, which may impose difficulty for the fault location.

Distance relays are among the most commonly used power systems protection devices. Distance relays are mainly used for transmission line protection is the interconnected networks. It is usually consists of three zones: the main protection zone for detecting and eliminating fault in $100 \%$ of the transmission line, it must operate without any time delay. The first zone backup protection for protecting about $80 \%$ of transmission line, serve as an instantaneous backup protection for the main protection zone. And then, the second zone is usually backup protection that set to $120 \%-150 \%$ of the length of the line, serves as backup protection for adjacent transmission lines. A breaker failure protection scheme can also be employed. Whenever a breaker failure is detected, a tripping command is sent to remote breakers without anytime delay [4]. it can be showed in Figure 1.

IJEEI Vol. 2, No. 1, March 2014: $1-12$ 


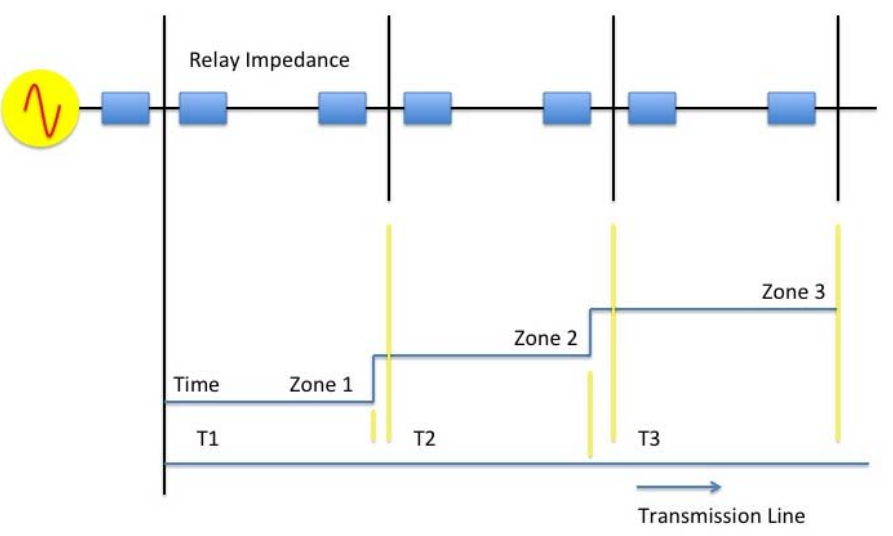

Figure 1. Setting of time for each distance relay

While the transmission line disturbed, then the distance relay can show the decrease from impedance of transmission line, then distance relay will get respond. Diagram of distance relay can be show in Figure 2. Distance relays can be measure the voltage on relay points and noise current visible from relay, by dividing the amount of voltage and current, the impedance to the point of occurrence interference can be determined.

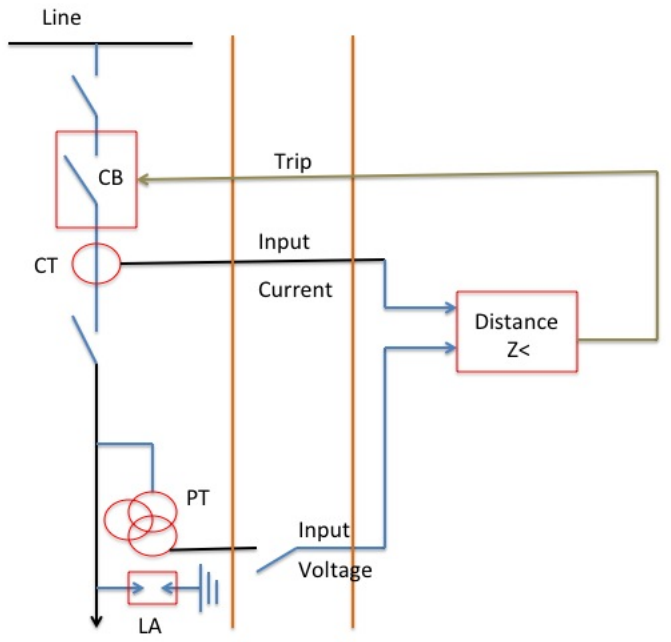

Figure 2. Circuit of distance relay

Distance relay will work while is comparing impedance interference to make measure impedance setting on the distance relay, provided it; if the value is less interference impedance rather than setting the impedance distance relay, and then distance relay will work. And then, if the value of impedance is greater disruption or equal to the impedance setting distance relay, it will know the distance relay will not work.

\section{Research Method}

This simulation is based on real conditions in the field area with the mutually interconnected transmission system. The power supplied from two sources generated using power grid model swing generator two unit with capacity 26.6 MVA (TL Lembu) and generator 
three unit with capacity 45 MVA (Kt Panjang) wye connected. Then interconnected to other substation transmission around Riau Region.

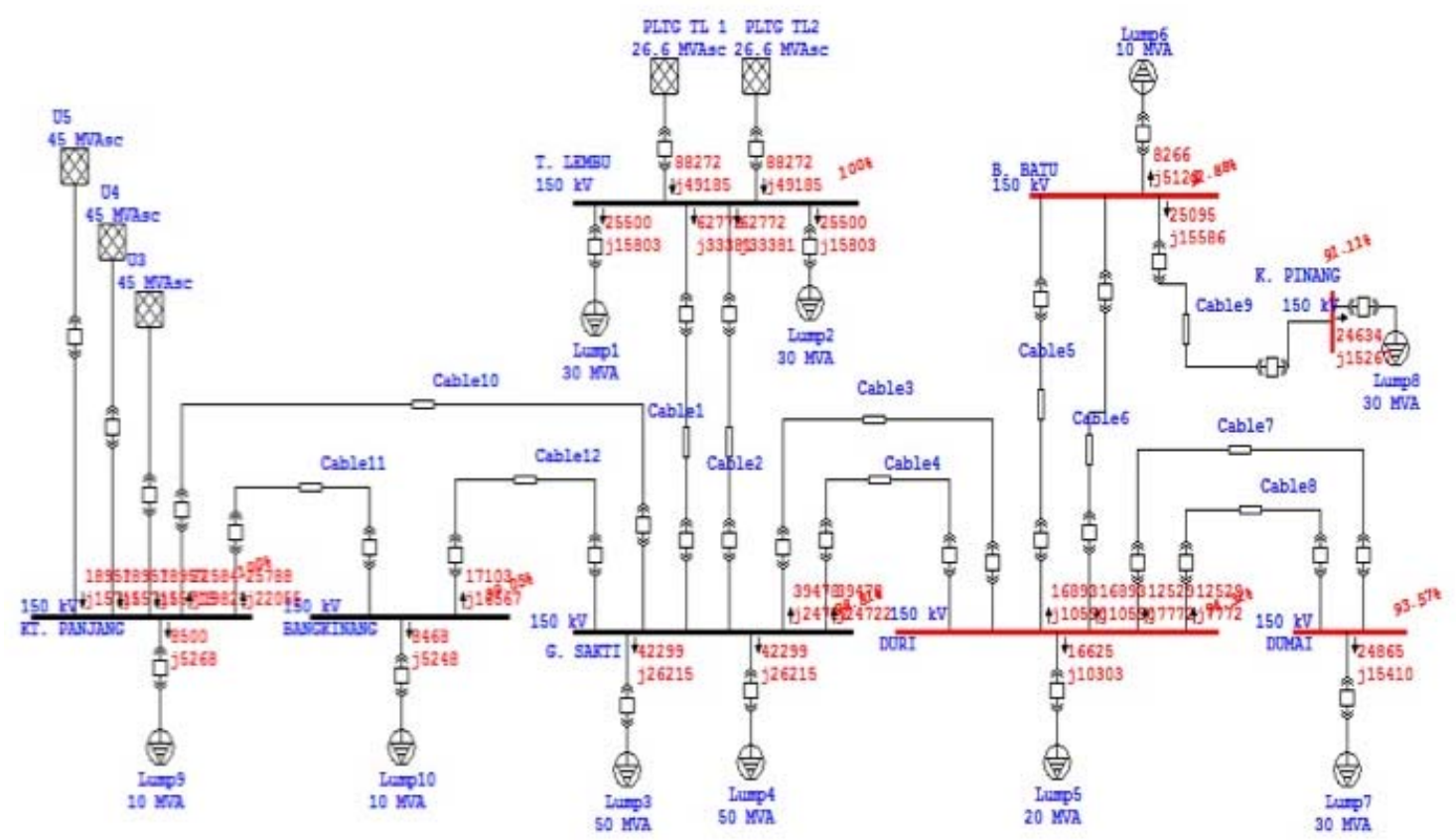

Figure 3. One line diagram of energy generated from power grid

Electrical power system in Riau region is an over head line transmission with nominal voltage of $150 \mathrm{kV}$. Fitted with a line length of a particular type ACSR conductor. The ETAP (Electrical Transient Analyzer Program) software experiments based on real system conditions with the values of the input variables, then obtained output values based on the simulation results run load flow analysis. It can show in table 1.

Table 1. Branch connection

\begin{tabular}{|l|c|c|c|}
\hline \multicolumn{1}{|c|}{ SUBSTATION } & $\mathbf{R}$ & $\mathbf{X}$ & $\mathbf{Z}$ \\
\hline TL Lembu to G Sakti & 1.38 & 0.96 & 1.68 \\
\hline TL Lembu to G Sakti & 1.38 & 13.53 & 1.68 \\
\hline G sakti to Duri & 7.85 & 5.44 & 9.54 \\
\hline G Sakti to Duri & 7.85 & 76.85 & 9.54 \\
\hline Duri to B batu & 4.75 & 5.27 & 7.10 \\
\hline Duri to B Batu & 4.75 & 72.17 & 7.10 \\
\hline Dumai to Duri & 3.96 & 2.74 & 4.81 \\
\hline Dumai to Duri & 3.96 & 2.74 & 4.81 \\
\hline Kt Pinang to B Batu & 4.56 & 3.16 & 5.55 \\
\hline Kt Panjang to G Sakti & 2.66 & 2.95 & 3.98 \\
\hline Kt Panjang to Bangkinang & 1.88 & 2.09 & 2.81 \\
\hline Bangkinang to G Sakti & 0.67 & 0.75 & 1.01 \\
\hline
\end{tabular}

IJEEI Vol. 2, No. 1, March 2014 : 1 - 12 


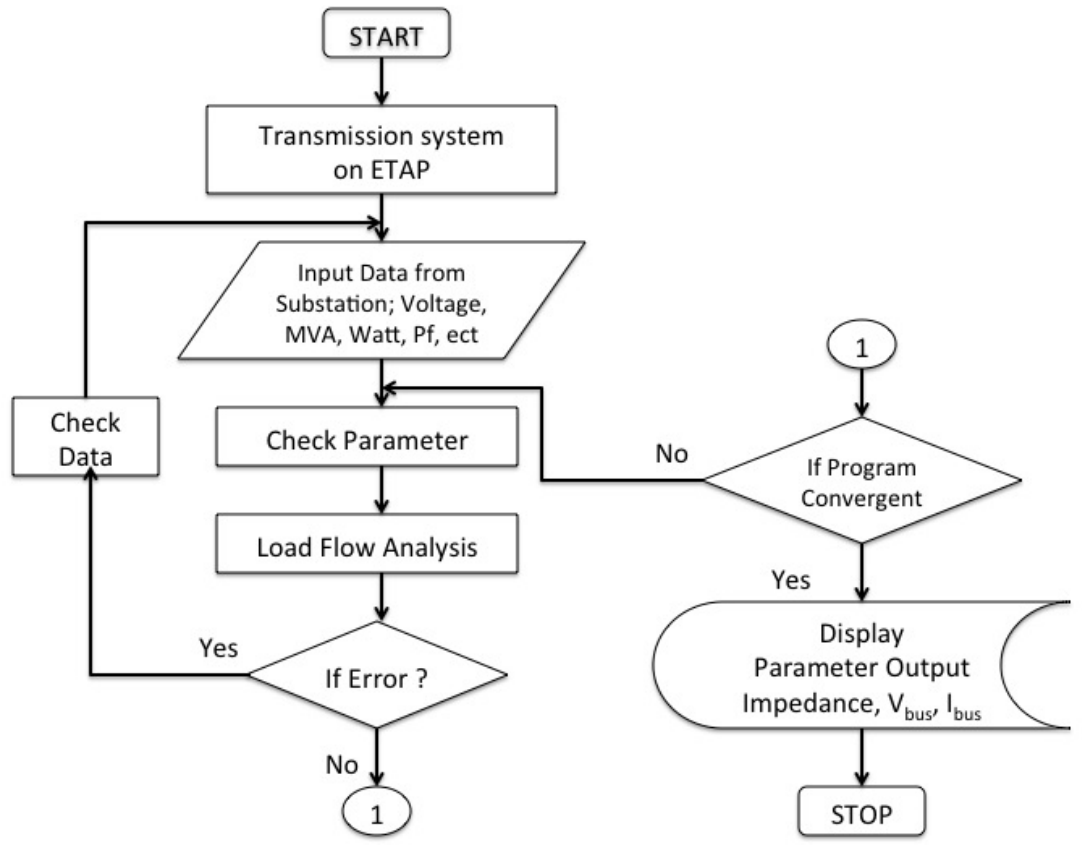

Figure 4. Flowchart simulation of ETAP

The simulation and result under normal conditions that previously have been done. Modeling setting a disturbance in one long line 3 between the bus Garuda Sakti and bus Duri in accordance the conditions of real disorder as has happened in the field on the $27^{\text {th }}$ of September 2011. Disruption occurs at a fault location line length is $22.4 \mathrm{Km}$ long line between bus Garuda Sakti towards bus Duri.

Table 2. The simulation result current conditions disorder in ETAP

\begin{tabular}{|c|c|c|c|c|}
\hline \multicolumn{2}{|c|}{ SUBSTATION } & \multirow{2}{*}{ VOLTAGE (kV) } & \multicolumn{2}{|c|}{ LOADFLOW } \\
\hline From & To & & Voltage (kV) & Current (A) \\
\hline \multirow[t]{2}{*}{ TL. Lembu } & G Sakti & 150 & 150 & 273 \\
\hline & G Sakti & 150 & 150 & 273 \\
\hline \multirow[t]{6}{*}{ G Sakti } & TL Lembu & 150 & 148.22 & 273 \\
\hline & TL Lembu & 150 & 148.22 & 273 \\
\hline & Duri & 150 & 148.22 & 181 \\
\hline & Duri & 150 & 148.22 & 181 \\
\hline & K Panjang & 150 & 148.22 & 112 \\
\hline & Bangkinang & 150 & 148.22 & 107 \\
\hline \multirow[t]{6}{*}{ Duri } & G Sakti & 150 & 141.479 & 181 \\
\hline & G Sakti & 150 & 141.479 & 181 \\
\hline & B Batu & 150 & 141.479 & 81 \\
\hline & B Batu & 150 & 141.479 & 81 \\
\hline & Dumai & 150 & 141.479 & 60 \\
\hline & Dumai & 150 & 141.479 & 60 \\
\hline \multirow[t]{3}{*}{ B Batu } & Duri & 150 & 139.315 & 81 \\
\hline & Duri & 150 & 139.315 & 81 \\
\hline & Kt Pinang & 150 & 139.315 & 112 \\
\hline \multirow[t]{2}{*}{ Dumai } & Duri & 150 & 140.352 & 60 \\
\hline & Duri & 150 & 140.352 & 60 \\
\hline Kt Pinang & B Batu & 150 & 136.672 & 122 \\
\hline \multirow[t]{2}{*}{ Kt Panjang } & G Sakti & 150 & 150 & 112 \\
\hline & Bangkinang & 150 & 150 & 145 \\
\hline \multirow[t]{2}{*}{ Bangkinang } & G Sakti & 150 & 107 & 107 \\
\hline & Kt Panjang & 150 & 145 & 145 \\
\hline
\end{tabular}

All circuit breakers are moving toward to load in the open circuit, the current in the load flow analysis that was using simulation, and then the $22.4 \mathrm{Km}$ long line bus mounted a shadow 
and the shadow disturbance on the bus by using short circuit in case studid to obtain the data as follows in table 3.

Table 3. The short circuit report

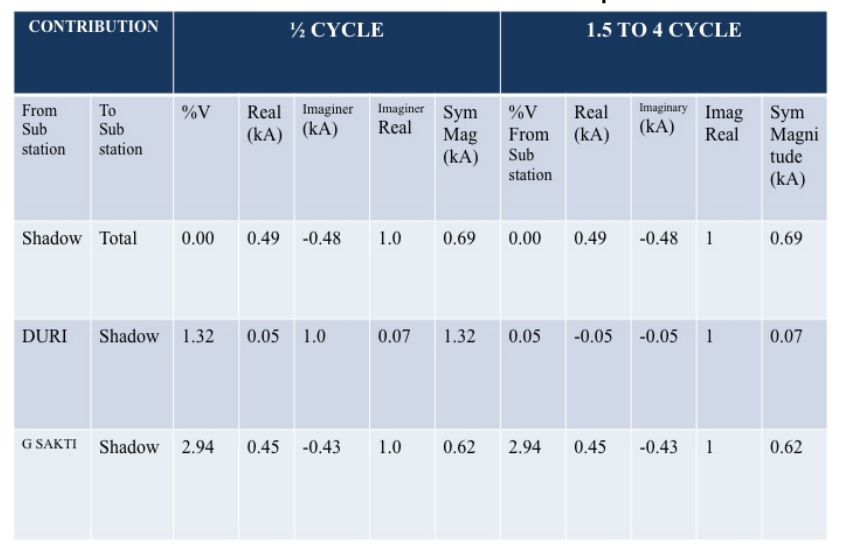

\subsection{Backpropagation Neural Network Modeling}

Backpropagation Neural Network (BNN) can be used to solve problems in this research to determine the zone of disturbance in an electric power system thus can make the right decision by given input pattern in testing. BNN is one model of feed forward neural network using supervised training which is based on the algorithm error back propagation training rule based on error correction. The process of error back propagation consists of two stages that are: feed forward and feed backward.

Every neuron in each has the function of activation. Each neuron in the input using the identify activation function. Each neuron in the hidden layer using a non linear activation function, continuous activation functions used derivative and monotonous rise. Each neuron output use the same activation function is linear activation function. The activation functions must have a derivative usage in the algorithm method for BNN which using derivative of the activation in each to improve weights of neural network. Hidden layer is using the linear activation function; BNN can solve the problem because the composition of linear functions is linear.

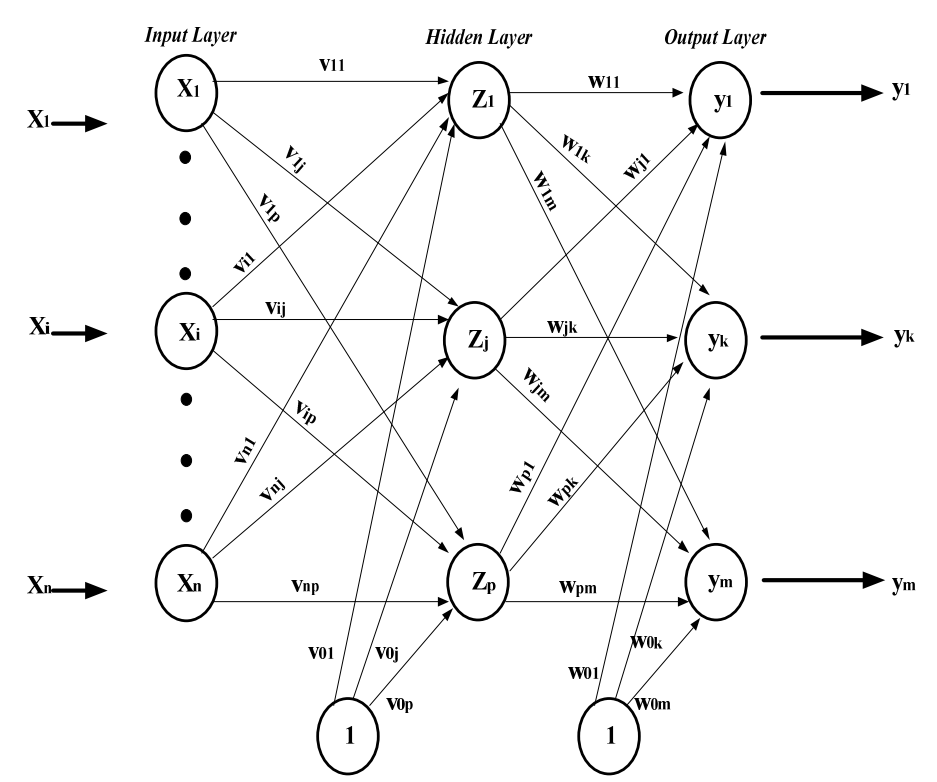

Figure 5. The architecture back propagation neural network

IJEEI Vol. 2, No. 1, March 2014: 1 - 12 
Algorithm of BNN Model:

Stage 1: Initialized weights.

Stage 2: There are no specific criteria for determining the value that the algorithm stops.

Feed forward:

Stage 3: Each neuron input $\left(x_{i}, i=1, \ldots, n\right)$ receives signals $x_{i}$ and sends value is the value of all these neuron in the next.

Stage 4: Each hidden neuron receives input $\left(z_{j}, j=1, \ldots p\right)$ in the form of the result of multiplying the value of each signal with the weight on the line connected to the hidden layer;

$$
z_{i n_{j}}=v_{0 j+} \sum_{i=1}^{n} x_{i} v_{i j}
$$

Use the activation function to compute its output signal;

$$
z_{j}=f\left(z_{i n_{j}}\right)=\frac{1}{1+e^{-z_{-} i n_{j}}}
$$

Stage 5: Each neuron output; $\left(y_{k}, k=1, \ldots, m\right)$ accept input in the form of the theoretical value of the output of each hidden layer with a weight on the line connected to the output layer;

$$
y_{i n_{k}}=w_{0 k}+\sum_{j=1}^{p} z_{j} w_{j k}
$$

Use the activation function is to calculate the output signal;

$$
y_{k}=f\left(y_{i n_{k}}\right)=\frac{1}{1+e^{-y \_i n_{k}}}
$$

Backpropagation of Error :

Stage 6: Calculate the output factor of error in each output layer by layer; $\left(y_{k}, k=1, \ldots, m\right)$

$$
\partial_{k}=\left(t_{k}-y_{k}\right) f^{\prime}\left(y_{i n_{k}}\right)=\left(t_{k}-y_{k}\right) y_{k}\left(1-y_{k}\right)
$$

$\partial_{k}$ : error units that will be used in the changing weight layer.

Calculate of the spart weight change $j k$ which will be used later to change the weight $w_{j k}$ rate perception $\alpha$

$\left(z_{j}=j=1, \ldots, p\right)$ To update the hidden layer bias to the output layer;

$$
\Delta w_{0 k}=\alpha \partial_{k}
$$

Stage 7: Calculate the hidden layer based on the error factor in each hidden layer; $\left(z_{j}=j=\right.$ $1, \ldots, p)$ assumed $\partial$ input;

$$
\partial_{n e t_{j}}=\sum_{k=1}^{m} \partial_{k} w_{j k}
$$

The factorðhidden layer;

$$
\partial_{j}=\partial_{i n_{j}} f^{\prime}\left(z_{i n_{j}}\right)=\partial_{-} i n_{j} z_{j}\left(1-z_{j}\right)
$$

Calculate of the spart weight change; $v_{i j}$

$$
\Delta V_{i j}=\alpha \partial_{j} X_{i}, j=1,2, \ldots, n
$$

Which will be used later to change the weight; $j=1,2, \ldots, p$ and $i=1,2, \ldots, n$ To update the weights with the input layer hidden layer;

$$
\Delta V_{0 j}=\alpha \partial_{j}
$$


Renewed Weight and Bias:

Stage 8: Each neuron output $\left(y_{k}, k=1, \ldots, m\right)$ update the weights and bias $(j=1, \ldots, p)$;

$$
w_{j k}(n e w)=w_{j k}(\text { old })+\Delta w_{j k}
$$

Every neuron hidden; $\left(z_{j}, j=1, \ldots, p\right)$ to update the hidden layer $\operatorname{bias}(i=1, \ldots, n)$;

$$
v_{i j}(\text { new })=V_{i j}(\text { old })+\Delta v_{i j}
$$

Stage 9: Test the value that has been determined to quit.

After learned the process, the network above can be used for the testing process. In this case only the feed forward measures are used to determine the output results of the network.

Table 4. Description of Notation

\begin{tabular}{|c|l|}
\hline \multicolumn{2}{|c|}{ Description of Notation is used; } \\
\hline$\delta_{\mathrm{k}}$ & The correction of error from the output layer to hidden layer \\
\hline$\delta_{\mathrm{j}}$ & The correction of error from the hidden layer to input layer \\
\hline$\alpha$ & Learning rate \\
\hline $\mathrm{x}_{\mathrm{i}}$ & Input unit $\mathrm{i}$ \\
\hline $\mathrm{v}_{0 \mathrm{j}}$ & Bias for neuron hidden $\mathrm{j}$ \\
\hline $\mathrm{z}_{\mathrm{j}}$ & Neuron hidden $\mathrm{j}$ \\
\hline $\mathrm{w}_{0 \mathrm{k}}$ & Bias for neuron output $\mathrm{k}$ \\
\hline $\mathrm{y}_{\mathrm{k}}$ & Neuron output $\mathrm{k}$ \\
\hline $\mathrm{t}_{\mathrm{k}}$ & Target BNN \\
\hline
\end{tabular}

The results of the simulation modeling using ETAP software go on if returned as input to matlab programming. Rated output at normal conditions in the system was produced the previous ETAP simulation, reused for a new input values in Matlab simulations. The value is in the form of bus voltage magnitude value, the current in the line length and impedance as the target output value, which used for the training of neural network method. In different to the training process, the current state of the system modeling interference occurs, the value of the results simulation ETAP for a new input values in programming Matlab then simulation to be used for the testing process, the form of input noise current of each line length and voltage disturbances respective bus. In the process of testing, the target values for the impedance settings are used constant as the value on the training process, so that it can detect the location or zone of disturbance in the system and can be known protective equipment decisions that work (trip) in the location of the disorder. The data can be seen in table 5. 
Table 5. Input current normal and disturbance conditions disorders matlab simulation

\begin{tabular}{|c|c|c|c|c|c|c|c|c|}
\hline \multicolumn{5}{|c|}{ Normal Condition } & \multicolumn{4}{|c|}{ Disturbance Condition } \\
\hline Sromstation & Vo/kAGGE & Substation & CURRENT & IMPEDANCE & Fromstation & volfitge & To Substation & CUREFT \\
\hline \multirow[t]{2}{*}{ *Tl Lembu } & 150 & G Sakti & 273 & 549.45 & *Tl Lembu & 5.06 & G Sakti & 0 \\
\hline & 150 & G Sakti & 273 & 549.45 & & 5.06 & G Sakti & 0 \\
\hline \multirow[t]{6}{*}{ G Sakti } & 148.22 & T Lembu & 273 & 542.93 & G Sakti & 1.98 & Tl Lembu & 0 \\
\hline & 148.22 & T Lembu & 273 & 542.93 & & 1.98 & Tl Lembu & 0 \\
\hline & 148.22 & Duri & 181 & 818.89 & & 1.98 & Shadow & 620 \\
\hline & 148.22 & Duri & 181 & 818.89 & & 1.98 & Duri & 0 \\
\hline & 148.22 & Kt Panjang & 115 & 1288.87 & & 1.98 & Kt Panjang & 0 \\
\hline & 148.22 & Bangkinang & 92 & 1611.08 & & 1.98 & Bangkinang & 0 \\
\hline \multirow[t]{6}{*}{ Duri } & 141.48 & G Sakti & 181 & 781.75 & Duri & 4.41 & Shadow & 66 \\
\hline & 141.48 & G Sakti & 181 & 781.75 & & 4.41 & G Sakti & 0 \\
\hline & 141.48 & B Batu & 81 & 1746.65 & & 4.41 & B Batu & 0 \\
\hline & 141.48 & B Batu & 81 & 1746.65 & & 4.41 & B Batu & 0 \\
\hline & 141.48 & Dumai & 60 & 2357.98 & & 4.41 & Dumai & 0 \\
\hline & 141.48 & Dumai & 60 & 2357.98 & & 4.41 & Dumai & 0 \\
\hline \multirow[t]{3}{*}{ B Batu } & 139.32 & Duri & 81 & 1719.93 & B Batu & 1.97 & Duri & 0 \\
\hline & 139.32 & Duri & 81 & 1719.93 & & 1.97 & Duri & 0 \\
\hline & 139.32 & Kt Pinang & 122 & 1141.92 & & 1.97 & Kt Pinang & 0 \\
\hline \multirow[t]{2}{*}{ Dumai } & 140.35 & Duri & 60 & 2339.2 & Dumai & 1.97 & Duri & 0 \\
\hline & 140.35 & Duri & 60 & 2339.2 & & 1.97 & Duri & 0 \\
\hline Kt Pinang & 136.672 & B Batu & 122 & 1120.26 & Kt Pinang & 1.97 & B batu & 0 \\
\hline \multirow[t]{2}{*}{ *Kt Panjang } & 150 & G Sakti & 115 & 1304.34 & ${ }^{\circ} \mathrm{Kt}$ Panjang & 8.12 & G Sakti & 0 \\
\hline & 150 & Bangkinang & 130 & 1153.84 & & 8.12 & Bangkinang & 0 \\
\hline \multirow[t]{2}{*}{ Bangkinang } & 148.58 & G sakti & 92 & 1615.02 & Bangkinang & 5.39 & G Sakti & 0 \\
\hline & 148.58 & Kt Panjang & 130 & 1142.93 & & 5.39 & Kt Panjang & 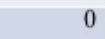 \\
\hline
\end{tabular}

In different the training process, the occurs current state of the system modeling interference, the results of value simulation ETAP (table 2 and 3) reused for a new input values in programming Matlab simulation to be used for the testing process, the form of input noise current of each line length and voltage disturbances every bus. In the process of testing the target values for the impedance settings are used constant as the value on the training process, so that it can be detected the location or zone of disturbance in the system and can be known protective equipment decisions that work (trip) the location of the disorder. The data can be seen in table 5.

\section{Results and Analysis}

The process of training and testing of the method in modeling the Back propagation Neural Network, by using the value of learning rate and hidden layer are determined by reference to the source, the result was obtained the back propagation method can detect the output of the work process in the form of output protection method that $C B$ was connected electric power systems, where it done modeling interference testing in one of the long line between lines of Garuda Sakti Bus and Bus Duri, back propagation neural network modeling output CB detect the location or zone disrupted the zone 1 and zone 2. The simulation of modeling methods BPNN and table 6 and 7, it can be seen in the current system interference with reading protection equipment installed $\mathrm{CB}$ respective bus systems in substations, the BNN will be able to detect the location or zone of disturbance. BNN on the distance relay will detect first the location of the disruption that occurred in zone 1, because of the zone 1 is the primary protection zone along $80 \%$ of the line. Then if the interference cannot be secured along the zone 1 , the BNN in the distance relay will detect the fault location occurred in zone 2 . The results of the modeling using BNN can be seen modeling method and detect the location or zone of disturbance more accurate. Almost as long as line system is the main zone of protection in other words, BNN can handle and overcome the problem of detecting interference in electrical power system line transmission. 
Table 6. Process Training and Testing BNN

Input Neurons of BNN

The number of input layer neurons 20 neurons

The number of hidden layer neurons 37 neurons

The values of neuron output layer 24 neurons

Target of error

0.001

Learning rate $(\alpha)$

0.5

The number of iterations

48,370

Table 7. Simulation of Results Output using BNN

\begin{tabular}{|l|l|l|}
\hline The Zone of Protection & \multicolumn{1}{|c|}{ Fault Location (Bus) } & Protective Devices Work \\
\hline Zone 1 & T1 Lembu 1, G Sakti 1, T1 Lembu & CB1, CB2, CB3, CB4, CB5, CB6, \\
& $\begin{array}{l}\text { 2, G Sakti 2, G Sakti 1, Duri 1, G } \\
\text { Sakti 2, Duri 2, B Batu, Duri 1, B }\end{array}$ & CB7, CB8, CB9, CB10, CB11, CB13, CB14, CB15, CB16, \\
& $\begin{array}{l}\text { CBatu 2, Duri 2, Duri 1, Dumai 1, } \\
\text { Duri 2, Dumai 2, B Batu, Kt } \\
\text { Pinang, Kt Panjang, G Sakti, Kt }\end{array}$ & CB22 \\
& $\begin{array}{l}\text { Panjang, Bangkinang } \\
\text { Zone CB20, CB21, }\end{array}$ & \\
\hline Bangkinang, G Sakti & CB23, CB24
\end{tabular}




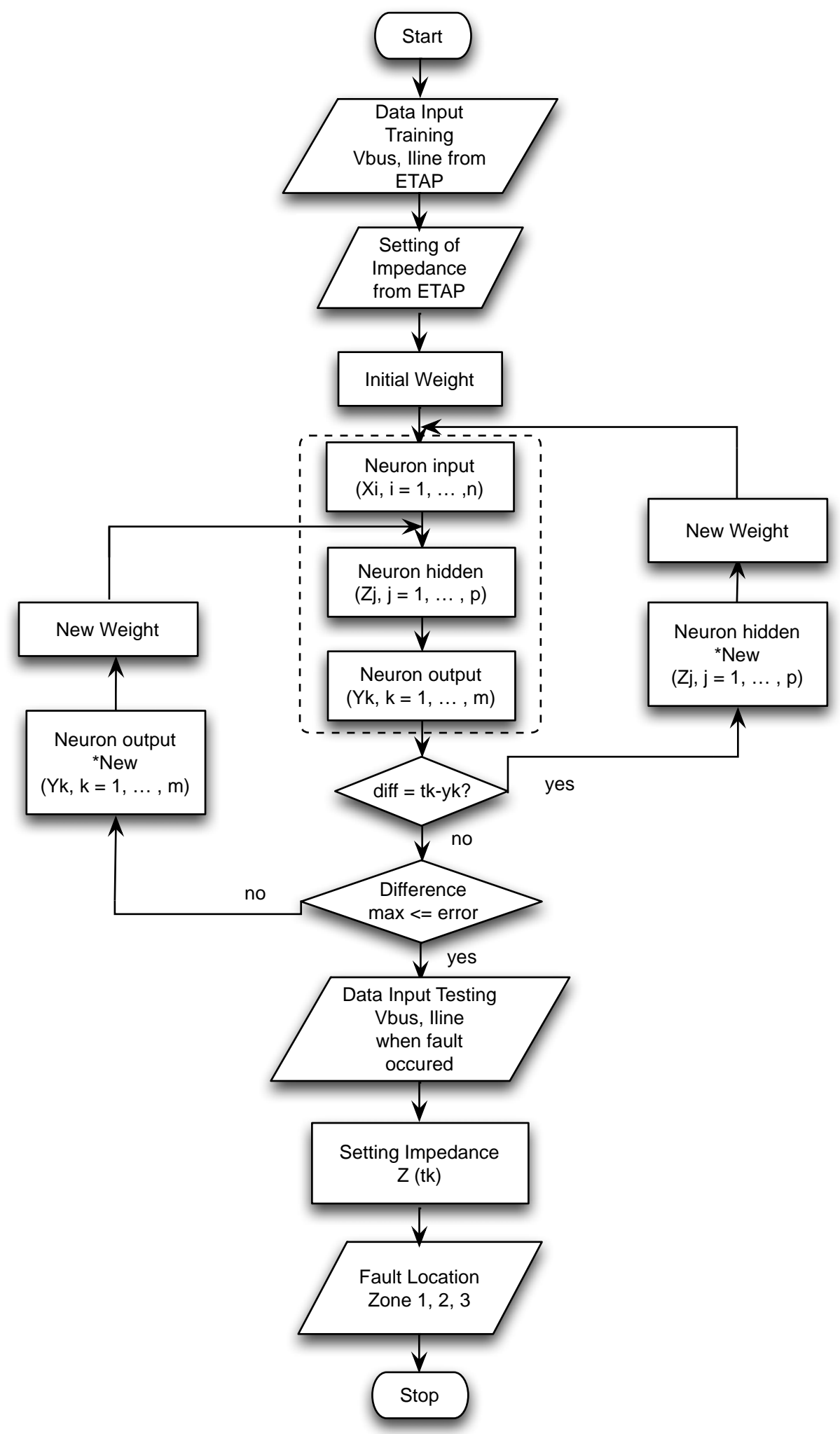

Figure 6. Flowchart BNN generated by simulation of Matlab 


\section{Conclusion}

Distance relay is one of the relay for the selective because of zone protection, at the zone 1 can detect $80-90 \%$ of the line fault location on transmission substations. Zone 2 protects $50 \%$ of the next fault location and the zone 3 can reach $25 \%$ of interference on the line transmission then the next substation if the distance relay is able to know the location and distance of fault, as well as selecting a network disconnect the nearest disturbance to open. So the probability of relay protection failure is very small. The prediction of the BNN on distance relays can provide information such as the location or zone protection interference in the transmission system. The selection of parameters and weights for the predicted value based on the value of the smallest fault testing. Success in predicting affected by the number of hidden layer and the value of learning rate used. The input layer with one variable model will provide more accurate test results. Modeling setting a disturbance in one long line transmission between bus Garuda Sakti and bus Duri in accordance with the conditions of real disorder as has happened in the field. The tests results show that correct diagnoses have been achieved from analysis of BNN output.

\section{References}

[1] ZE Aygen, S Seker, M Bagriyanik, FG Bagriyanik and E Ayaz. "Fault Section Estimation in Electrical Power System using Artificial Neural Network Approach". IEEE. 1999.

[2] EM Meza, JCS de Souza, MTh Schilling, and MBDC Filho. "Exploring Fuzzy Relations for Alarm Processing and Fault Location in Electrical Power Systems". IEEE. 2001.

[3] PK Dash, AK Pradhan, and G Panda. "A Novel Fuzzy Neural Network Based Distance Relaying Scheme". IEEE Transaction on power Delivery. 2000; 15(3).

[4] ZE Aygen, S Seker, M Bagriyanik, FG Bagriyanik and E Ayaz. "Fault Location in Electrical Power Systems Using Intelligent Systems Techniques". IEEE Transactions on Power Delivery. 2001; 16(1).

[5] HC Chin. "Fault Section Diagnosis of Power System Using Fuzzy Logic". IEEE Transactions on Power Systems. 2003; 18(1).

[6] WM Lin, CH Lin, and ZC Sun. "Adaptive Multiple Fault Detection and Alarm Processing for Loop System with Probabilistic Network". IEEE Transactions on Power Delivery. 2004; 19(1).

[7] JCS de Souza, EM Meza, MTh Schilling, and MBC Filho. "Alarm Processing in Electrical Power Systems through a Neuro Fuzzy Approach". IEEE Transactions on Power Delivery. 2004; 19(2).

[8] G Cardoso, Jr JG Rolim, and HH Zurn. "Application of Neural Network Modules to Electric Power System Fault Section Estimation". IEEE Transactions on Power Delivery. 2004; 19(3).

[9] Azriyenni, MW Mustafa. "Performance Neuro-Fuzzy for Power System Fault Location". International Journal of Engineering and Technology. 2013; 3(4).

IJEEI Vol. 2, No. 1, March 2014: 1 - 12 